\title{
ISKOLAI PREVENCIÓ ÉS AZ EVOLÚCIÓ LOGIKÁJÁNAK ELLENTMONDÁSAI
}

\author{
MIHÁLYI PÉTER \\ Budapesti Corvinus Egyetem Makroökonómia Tanszék
}

Nem helyes azt elvárni az iskoláktól, hogy minden létező problémára ők készítsék fel a gyerekeket. A tanulmány legfőbb mondanivalója az, hogy a 6-14 éves korosztálynak egy olyan élet- és viselkedésstratégiát kell megtanítani, amely fontos területeken ellentmond a humán evolúció évezredek során kialakult logikájának. A túlélés genetikai programja a rövid távú optimalizálásra ösztönöz. A hosszú élet, az egészséges öregkor viszont azt feltételezi, hogy az emberek ellenállnak a rövid távú örömforrásoknak. A jó hír az, hogy a bizalom, az önkontroll, az akaraterő fejlesztése tanítható - erre nyilvánvalóan a mélyszegénységben élő családok gyermekeinek van a legnagyobb szükségük. Ez kellene, hogy legyen az iskolai prevenciós programok elsőszámú célja.

Kulcsszavak: evolúció, azonnali szükségletkielégítés, önuralom, társadalmi rétegzettség, romakérdés

It is unwise to expect from schools to prepare children to all future challenges. The takehome message of the present paper is that the 6-14 age groups should be taught to pursue behavioural strategies which in themselves, in important ways, contradict the logic of biological evolution. Humans, and of course children as well, are wired to short-term optimization. Long and healthy life requires long-term optimization. The good news is that trust, self-control and the development of will power can be taught in schools. This is most important for children coming from poor families.

Keywords: evolution, immediate satisfaction, self-control, social stratification

\section{Bevezetés}

A köznapi ember - és ebből kifolyólag a legtöbb politikus is - hajlamos azt gondolni, hogy a prevenció egyfajta össztársadalmi malacpersely, amibe a kormányzat ma betesz 1000 forintot, és 1-10-20 év múlva majd 10 ezer forintot tud ki-

Levelező szerző: Mihályi Péter, Budapesti Corvinus Egyetem, Makroökonómia Tanszék, 1093 Budapest, Fővám tér 8. E-mail: peter@mihalyi.com 
venni belolle. „A prevenció a legjobb egészségügyi befektetés!” - szokták mondani. Ötven évvel ezelőtt ez hellyel-közzel igaz volt (pl. tbc-szürés), ma már nem. Elsősorban azért nem, mert a népesség mai tudása lényegesen kiterjedtebb, anyagi lehetőségei pedig sokkal nagyobbak - ezért az államilag szervezett prevenció relatív többlethasznossága sokkal kisebb, mint évtizedekkel korábban.

Ezen a fogalmi kereten belül az iskolai prevencióra - szükebben és pontosabban fogalmazva: az általános és középiskolákban zajló különféle elsődleges (primer) prevenciós erőfeszítésekre - helyesebb úgy gondolni, mint az oktató-nevelő munka kiegészítésére, amely szükségszerüen többletköltségekkel jár. Olyan összefüggéseket kell megtanítani a diákoknak, amilyeneket egyébként máshonnan nem ismernek, olyan készségeket kell elsajátítaniuk, amilyeneket a legtöbben otthon vagy a barátaiktól nem tanulhatnak meg. A jelen tanulmány legfóbb mondanivalója az, hogy a 6-14 éves korosztálynak egy olyan életés viselkedésstratégiát kell megtanitani, amely fontos területeken ellentmond a bumán evolúció évszázezredek során kialakult logikájának. ${ }^{1}$ Ugyanakkor nem helyes azt elvárni az iskoláktól, hogy minden létező problémára ők készítsék fel a diákokat. Ám az idevágó hatályos rendelkezés sajnos éppen ezt írja elő:

„A nevelési-oktatási intézmény mindennapos müködésében kiemelt figyelmet kell fordítani a gyermek, a tanuló egészséghez, biztonsághoz való jogai alapján a teljes körű egészségfejlesztéssel összefüggő feladatokra, amelyek különösen

a) az egészséges táplálkozás,

b) a mindennapos testnevelés, testmozgás,

c) a testi és lelki egészség fejlesztése, a viselkedési függőségek, a szenvedélybetegségekhez vezető szerek fogyasztásának megelözése,

d) a bántalmazás és iskolai erőszak megelőzése,

e) a baleset-megelőzés és elsősegélynyújtás,

f) a személyi higiéné területére terjednek ki." ${ }^{2}$

Ez így, együtt nyilvánvalóan túl sok. Helyesebb lenne azokra a területekre fókuszálni, ahol az iskola elvárhatóan többletinformációt, többletsegítséget nyújt a gyerekeknek. Egyes fontos témákat, mint például az elsősegélynyújtás, célszerübb a nem iskolai képzési formákhoz (pl. gépjárművezetői jogosítvány megszerzése) kapcsolni.

Nagyon fontos már itt a bevezetésben leszögezni, hogy Magyarországon ma is kiválóan müködik a prevenciós rendszer legfontosabb eleme, az iskolai kötelező védőoltások rendszere, a végletesen központosított tervgazdaság egyik „pozitív” hagyatéka. ${ }^{3}$ Ezt ter-

1 Itt és a továbbiakban nem fogunk kitérni az egészség-gazdaságtan terminológiája szerinti „másodlagos” és „harmadlagos” prevencióra, jóllehet mindkettőre van példa az iskolában. Definíció szerint a másodlagos (szekunder) prevenció célja a korai stádiumban lévő esetek gyors, hatékony megoldása akkor, amikor még nem rögzült egy kedvezőtlen életvitel és/vagy állapot. Példa erre a fiatalok minél korábbi leszoktatása a dohányzásról vagy a kábítószer-használatról. A harmadlagos (tercier) prevenció lényege a károsító hatások, következmények kiküszöbölése, ártalomcsökkentés. Ilyen program például a tűcsere-program, mellyel meg lehet előzni a HIV-fertőzést vagy az ún. „esemény utáni tabletták” használata, amellyel a nem kívánt terhességet lehet megelözni.

2 EMMI 20/2012 (VIII.3.) rendelet 128.\$(3).

3 Összességében az átoltottság Magyarországon 98\%-os, ami világviszonylatban is kitűnő adat. A védőoltások többségét a gyermekek még az iskolás kor elérése előtt kapják meg. A hatályos rendelkezések szerint ma csak a 6. és 7. osztályos tanulók kapnak kötelező védőoltásokat ( $2+1$ alkalommal). EMMI (2018). 
mészetesen fenn kell tartani, és támogatni kell, hogy a nem kötelező oltásokhoz is minél szélesebb körben hozzá lehessen férni (pl. HPV elleni oltás).

\section{Az evolúció logikája}

Az emberi faj (és persze a gyermekek is) genetikailag a túlélésre és a reprodukcióra van programozva. A hosszú élet, a boldogság és az időskori fittség csak a modern kor értékei, amelyek alapvetően szemben állnak a genetikai örökséggel. A túlélés genetikai programja a rövid távú optimalizálásra ösztönöz. Erre szolgál a stressz is. Közismert, hogy a magasabb rendü élőlények hormonháztartása képes arra, hogy a másodperc tört része alatt mozgósítsa a szervezet tartalékenergiáit. Az emberi táplálkozás szokásrendszere arra van optimalizálva, hogy amikor van lehetőség élelmiszert fogyasztani, akkor minél többet együnk, minél könnyebben emészthető formában (pl. sütve) és zsír formájában tartalékoljuk a kalóriát a rosszabb időkre. Az sem véletlen, hogy az emberek többsége szereti az édességet. Ez oda vezethető vissza, hogy az újszülött kisbabákat rá lehessen venni a számukra jelentős erőfeszítést igénylő szopásra - ezért van magas cukortartalma az anyatejnek. Még pár száz évvel ezelőtt is igen kevesen élték meg a 60-70 éves életkort, ezért az emberi szervezet számára a késői öregkor ma ismert, rettegett betegségei valójában nem jelentettek valós kockázatot. Egy közismert irodalmi példát idézve, könnyü belátni, hogy a 15 éves Rómeó és a 14 éves Júlia annak tudatában szervezte életét, hogy várhatóan Rómeó előbb-utóbb elesik a csatamezőn vagy gyilkos merénylet áldozata lesz, Júlia nagy eséllyel bele fog majd halni a gyermekszülésbe, vagy betegség viszi el fiatalon a halálba. Miért ne akarták volna élvezni az életet fiatal korukban? Miért gondoltak volna arra, hogy mi lesz velük, ha megöregedek?

A 21. század életmódbeli kockázatai - a dohányzás, a túlzott alkoholfogyasztás, az elhízás stb. - mind-mind olyan dolgok, amelyek csak hosszú távon eredményeznek káros hatásokat. Éppen ezért semmi meglepő nincs abban, hogy az emberek többsége nagyon is hajlamos az elvben teljesíthető igények azonnali kielégítésére. Ezt az állítást könnyü ellenőrizni. Kérdezzünk meg egy dohányost, hogy miért dohányzik, ha tudja, hogy árt a saját egészségének. 10 megkérdezettből 9 azt fogja válaszolni, hogy azért dohányzik, mert dohányozni jó. A nemi élettel kapcsolatban fel sem érdemes tenni efféle kérdéseket. A szexuális drive már koragyermekkortól megfigyelhető. A fentiek okán valójában természetesnek kell tekintenünk, hogy iskoláskorú gyermekeink elöszeretettel követnek egészségükre káros megszokásokat. Az lenne a meglepő, ha nem így viselkednének. Éppen ezért nem lehet eléggé hangsúlyozni, hogy az iskolai prevenció tulajdonképpen azt a célt szolgálja, hogy a fiatalok megtanuljanak szembeszegülni az evolúció diktálta logikával.

\section{Irreverzibilis folyamatok}

Azt is látni kell, hogy az egészségünkkel kapcsolatos események az esetek igen jelentős részében (de nem minden esetben!) irreverzibilis folyamatok. Ilyen - például - az öregedés vagy a valamilyen születéskori vagy későbbi megbetegedéssel járó fogyatékosság. Napjainkban, amikor a közegészségügyi rendszer általános fejlettsége és a közepes szintü anyagi jólét miatt a csecsemő- és gyermekhalálozás minimális, az iskolás korosztály esetében leginkább a különféle balesetek jelentenek kockázatot. Az igen részletes és megbíz- 
1. táblázat: Az iskolás korosztályt fenyegető súlyos balesetek gyakorisága

\begin{tabular}{|c|c|c|}
\hline Esemény & USA gyakoriság & Becsült magyar adat \\
\hline $\begin{array}{l}\text { Nem szándékos, halálos sérülés az 1-19 éves kor- } \\
\text { osztályban }\end{array}$ & 12 ezer fö/év & $350-360$ fö/év $v^{*}$ \\
\hline $\begin{array}{l}\text { Esés következtében bekövetkezett nem halálos, } \\
\text { kórházi kezelést eredményező sérülés a } 19 \text { év alatti } \\
\text { korosztályban }\end{array}$ & 8 ezer fö/nap & $200-250$ fö/nap \\
\hline Halálos kerékpárbaleset a 0-14 éves korosztályban & 100 fö/év & 3-4 fö/év \\
\hline $\begin{array}{l}\text { Sérülés kerékpárbaleset nyomán a } 0-14 \text { éves kor- } \\
\text { osztályban }\end{array}$ & 254 ezer fö/év & 76 ezer fö/év \\
\hline $\begin{array}{l}\text { Lakáson belüli baleset miatti halál a 0-14 éves kor- } \\
\text { osztályban (pl. égés, fulladás, lőfegyver, mérgezés) }\end{array}$ & 2 ezer fö/év & 55-60 fö/év \\
\hline \multicolumn{3}{|c|}{$\begin{array}{l}\text { *Ez a két szám összhangban van a hivatalos magyar adatokkal. Az OGYI (2009) tanulmánya } \\
\text { szerint Magyarországon a 0-24 éves korosztályból, véletlen balesetek miatt, a 2005-2007-es évek } \\
\text { átlagában, } 326 \text { fiatal halt meg, ebből 246-an közlekedési baleset miatt (OGYI 2009: 15). } \\
\text { Forrás: Az amerikai CDC adatai alapján. ld. www.stanfordchildrens.org/en/topic/default?id= } \\
\text { accident-statistics-90-P02853 [Letöltve: 2019.11.27.] }\end{array}$} \\
\hline
\end{tabular}

ható amerikai statisztikák alapján megbecsülhetjük a tárgyunk szempontjából releváns balesetek gyakoriságát Magyarországra vonatkozóan is.

A balesetek példájából kiindulva rögtön szembekerülünk egy fontos kérdéssel: vajon indokolt-e, hogy az iskolákban baleset-megelőzési kampányt folytassunk és vállaljuk az ezzel járó anyagi költséget, illetve időráfordítást. Véleményem szerint ez nem indokolt. Normális körülmények között nevelkedő gyermekek tisztában vannak a rájuk leselkedő veszélyekkel, a család, a rendőrség és általában a média bőségesen szolgáltatja az ezzel kapcsolatos információkat, és az is rendjén való, hogy a rendőrség büntesse a szabálytalanul viselkedő fiatalokat (pl. kivilágítatlan kerékpár használata, sisak nélküli biciklizés, motorozás). A balesetek természetéből következik a gyors hatásmechanizmus: a sérüléssel járó fájdalom többnyire azonnali, és ezt minden iskolás gyermek pontosan tudja is. Ehhez a tapasztalat útján szerzett tudáshoz az iskola aligha tud érdemben hozzátenni. Ilyesmire nem érdemes költeni.

A prevenció - és ezen belül az iskolai prevenció - szükségessége éppen azokon a területeken a legfontosabb, ahol az oksági mechanizmusok közvetlen tapasztalás útján nem ismerhetők fel. Vagy azért, mert a kórokozó baktériumok és vírusok szabad szemmel nem láthatóak, vagy azért, mert a megbetegedés közvetlen oka és a következmények között időben nagyon nagy a távolság. Tipikus példa erre a dohányzás, a mértéktelen alkoholfogyasztás, bizonyos nemi betegségek, ahol a káros következmények általában csak évtizedekkel később jelentkeznek.

$\mathrm{A} z$ iskolai oktatás-nevelés részeként a diákokat fel kell készíteni arra is, hogy megértsék, az orvostudomány szakadatlanul fejlődik, a korábbi biztosnak vélt ismeretek tévesnek bizonyulhatnak. A változások lehetnek rossz és jó irányúak. Nevezetes példája a "rossz" változásnak, amikor az 1950-es évek végén (persze 2019-ből visszanézve nagyon régen) az orvostársadalom megbizonyosodott arról, hogy a dohányzás és a tüdőrák között szoros kapcsolat van - ezt évszázadokon keresztül senki sem sejtette. Jó irányú 
változás, hogy a 2000-es évek táján feltalálták az AIDS elleni gyógyszereket, nem is olyan sok évvel azután, hogy 1983-ban a WHO azt deklarálta, hogy az AIDS gyógyíthatatlan betegség; mindenki, aki megfertőződött, hamarosan meg fog halni. Napjainkban is bőven vannak gyógyíthatatlan betegségek (pl. Zika vírus), illetve olyanok, amelyek esetében éppen most csillant fel a remény, hogy gyógyszeres úton mégis kezelhető (pl. Ebola). Az itt felsorolt ismeretek mind olyanok, amelyekkel a globalizált világgazdaságban fel kell vértezni a mai iskolás gyermekeket, hiszen többségük egyszer vagy többször az életben biztosan el fog jutni távoli és egzotikus országokba is.

Az egészségügyi folyamatok irreverzibilitásának másik fontos alesete az addikcióval függ össze. Az addikció (függőség) fogalmát a szenvedélybetegséggel szinonim fogalomként szokás használni. Azokat a viselkedési formákat nevezzük így, amelyek fölött az egyén képtelen kontrollt gyakorolni, s ezért ezeket kényszeresen újra és újra végrehajtja, még akkor is, ha szándéka szerint szeretne az adott rossz szokástól megszabadulni. A dohányzás, az alkohol- vagy a drogfogyasztás esetében ez az összefüggés - mondjuk 14 éves kortól felfelé - általánosan jól ismert. A gyerekek tudják, hogy a szerhasználat függőséget alakít ki, amely egyfelől azzal a következménnyel jár, hogy a szer azonos adagjának folyamatos használata esetén jelentősen csökken az élvezeti hatás, másfelől azzal, hogy a fogyasztás leállása esetén a megvonási tünetek nagyon jelentős panaszokat tudnak okozni. Fontos tudni - és a diákoknak elmondani is -, hogy az addikció kialakulhat mindenféle szerhasználat nélkül is (pl. játékszenvedély, bulimia). Mind e mögött roppant bonyolult neurofiziológiai összefüggések állnak, amelynek részleteit az iskolás diákok aligha érthetik, de a probléma lényegét enélkül is pontosan tudják. Éppen ezért az ezzel kapcsolatos felvilágosításnak sem lehet túlságosan nagy hozadéka az iskolában.

$\mathrm{A} z$ orvostudomány mai állása szerint a fiatalkori elhízás is jó okkal nevezhető irreverzibilis folyamatnak. Az a gyermek, amelyik már a pubertás kor előtt elhízott, jó esélylyel egész életében túlsúlyos lesz. Egyfelől a túlzott kalóriabevitel az ok, másfelől viszont a mozgásszegény életmód. Paradox módon ez utóbbi is kapcsolódik az evolúciós logikához: egyfelől megszünt a (fizikai erőfeszítést követelö, tehát energiafogyasztó) gyermekmunka, másfelől nincs szükség arra, hogy a gyermekek naponta fél, egy vagy akár másfél órát gyalog menjenek az iskolába.

És végezetül érdemes röviden megemlíteni egy viszonylag új fejleményt, a bőrtetoválás elterjedését, melynek során különféle festékanyagokat visznek be a bőrbe. Alapesetben ez is irreverzibilis tett, a napjainkban elterjedten használt festékeket teljes mértékben nem lehet eltávolítani. Egyelőre az orvostudomány ezzel kapcsolatban nem szolgál különösebb fenyegetéssel, de nem lenne meglepő, ha 5-10 éves távlatban kiderülne, hogy a nagy felületen történő tetoválás, amelyet egyébként számos kultúrában évezredek óta müvelnek, mégis komoly egészségügyi károsodással jár (pl. bőrrák). Arra máris felfigyelt az orvostudomány, hogy a tetovált emberek MRI vizsgálata extrakockázattal jár, mert a vastartalmú festékek égési sebeket okozhatnak.

\section{Ha beteg lesz, maga tehet róla?}

$\mathrm{A} z$ egészség-gazdaságtan (health economics) nemzetközi irodalmában nagyjából az 1950-es évekre datálható az a felismerés, hogy az egészségre káros szenvedélyek előfordulása nem véletlenszerü, jóllehet az emberi faj biológiai adottságai lényegében azonosak. Minden vizsgálat azt mutatja, hogy még egy-egy országon belül is jelentős, szisztemati- 
kus különbségek vannak atekintetben, hogy az egyes társadalmi csoportok milyen mértékben képesek szembemenni azokkal az evolúciós késztetésekkel, amelyekről fentebb már szóltunk. A legjobb példa erre a dohányzás. Magyarországon - vagy a hozzá hasonló fejlettségű országokban - minden felnőtt és minden gyermek tudja, hogy a dohányzás ártalmas, a sok édesség fogyasztása és a kevés testmozgás általában elhízáshoz vezet stb. Mégis, a tapasztalat azt mutatja, hogy a dohányzás, az obezitás a szegényebb és kevésbé iskolázott családokban sokkal gyakoribb, mint a magas jövedelmű, képzettebb családokban.

A TÁRKI 2008-as felméréséből tudjuk, hogy a nem dohányzás a fővárosi, diplomával rendelkező felső-középosztály luxusa - hozzájuk képest minden más társadalmi csoport lényegesen többet dohányzik. 2009-2011 közötti, négy északkeleti megyében és Budapest X. kerületében végzett kutatás (Balázs et al. 2012) azt az eredményt hozta, a dohányzó roma nők miután várandósok lettek, 88,0\%-ban tovább folytatták a dohányzást, míg ugyanez az arány a nem romák között 47,4\% volt, tehát több mint fele részben abbahagyták a dohányzást. Ez a drasztikus különbség egyáltalán nem véletlen, és nem az információhiány az oka.

Walter Mischel, a Columbia Egyetem professzora az 1960-as években végezte el nagyhatású vizsgálatát, amely a pillecukor-kísérlet nevet kapta (marshmallow teszt). A kísérletben 4 éves gyerekeket állítanak választás elé: megehetik a tányérra helyezett pillecukrot azonnal, vagy ha várnak vele egy hosszabb időt (akár 20 percet is), akkor a vizsgálatvezető visszatértekor kettőt fognak kapni. A kutatók arra voltak kíváncsiak, hogy a gyerekek ebben a korban mekkora önfegyelemre képesek. Az első, majd a sokszor, sokak által megismételt kísérletek azt mutatták, hogy „a szegényebb körülmények között felnövő gyermekek amiatt nem képesek türelmesen várni a későbbi nagyobb jutalomra, mert korábbi tapasztalataik nem biztosítanak számukra garanciát ennek megvalósulására. Mindennapi tapasztalataik arra nevelik őket, hogy attól, hogy most bőségesen van mit enni, nem biztos, hogy holnap is így lesz." ${ }^{4}$ (Ahogy a magyar népi bölcsesség tartja: jobb ma egy veréb, mint holnap egy túzok.) Abból, hogy a felnőttek ígérnek valamit, még nem következik biztosan, hogy ígéreteiket be is fogják tartani. Rájuk tehát az evolúciós logika ma is kényszerítőleg hat: számukra kockázatos várakozni. „A jobb anyagi körülmények között élő gyermekek tapasztalatai általában nem adnak okot erre a bizalmatlanságra. Nem kell aggódniuk amiatt, hogy másnap nem lesz mit enniük, bízhatnak a körülöttük lévő (akár ismeretlen) felnőttekben is. Tehát a tehetősebb szülők gyermekei nyugodtabban késleltetik a jutalmat, nem kell amiatt szoronganiuk, hogy esetleg a várakozás alatt a meglévő is eltűnik." ${ }^{5}$ Ilyen értelemben tehát nagyon is a szociális helyzettől függ, hogy egy 4 éves gyermek ellen tud-e állni az azonnali kielégülés csábításának. Mischel utánkövetéses vizsgálatai szerint azok a jobb családból származó, óvodás gyermekek, akik képesek voltak az ellenállásra, életpályájuk során is egyre többféle előnyre tettek szert a szegényebb osztálytársaikhoz képest. A hosszú távú érdekeiket felismerve jobban teljesítettek az iskolában, nem kezdtek el dohányozni, kábítószert fogyasztani,

A modern videotechnikával megismételt teszt számos helyen megtalálható az interneten. Lásd például itt: https://mindsetpszichologia.hu/2018/07/06/atirodik-a-pszichologiatortenet-a-pillecukorteszteredmenyei-is-megkerdojelezodtek/ [Letöltve: 2019. nov. 27.]

Uo. 
nem híztak el, nem lettek terhesek kamaszkorban, nem követtek el büncselekményeket, és persze ilyen pályát befutva magasabb jövedelemre és vagyonra tettek szert. ${ }^{6}$

Nagyon fontos, hogy a prevenciós programok készítői, a lebonyolításban részt vevők alaposan átgondolják a fenti összefüggéseket. Egyfelől, semmiképpen nem szabad „hibáztatni” az alacsony jövedelmü, iskolázatlan családokat azért, mert egészségtelenül élnek. Jól hangzik azt mondani, hogy a családok fogyasszanak több zöldséget és gyümölcsöt, minél ritkábban járjanak „gyorsétterem”-be, lehetőleg ne konzervet, hanem friss élelmiszert vásároljanak. De egy pillanatra sem szabad megfeledkezni arról, hogy az egészségesebb élelmiszerek sokkal drágábbak, a McDonalds' kínálta ünneplő hangulat egy „normál” étteremben csak sokkal több pénzből varázsolható elő. Jól hangzik az a tanács, hogy a gyerekek sportoljanak minél többet az iskolában és az iskolán kívül - ám ez is sok pénzbe kerül (vagy az iskolának vagy a családnak). Másfelől viszont az Egyesült Államokban iskolai példák sora mutatta, hogy az önkontroll, az akaraterö fejlesztése tanitható - erre nyilvánvalóan a mélyszegénységben élö családok gyermekeinek van a legnagyobb szükségük. ${ }^{7} \mathrm{Ez}$ kellene, hogy legyen az iskolai prevenciós programok elsőszámú célja Magyarországon is.

\section{További adalékok az általános és középiskolai prevenció tervezéséhez}

Témánk szempontjából az elmúlt 10-15 év legfontosabb változása az internethasználat elterjedése a fiatalok körében. Számítógépen, laptopon és okos telefonon ma már minden információ lényegében ingyen elérhető: a Google mindent jobban tud, mint a legjobb népszerüsítő kiadvány, és nem „ciki” megkérdezni. Aki ezt figyelmen kívül hagyja, az teljes mértékben tévúton jár. ${ }^{8}$ Iskolaorvosok és szexuálpedagógusok elmondásából tudni lehet, hogy ez a lehetőség leginkább a hátrányos helyzetű családokból származó fiatalokat segíti, akiknek korábban megoldhatatlan problémát jelentett, hogy olyan „kényes” vagy egyenesen „tabu” témákban, mint a fogamzásgátlás, a nemi betegségek elkerülése, nem számíthattak semmiféle szülői segítségre. De természetesen az információhoz való jutás lehetősége minden egészségüggyel, életvezetéssel kapcsolatos tárgykörben ugyanígy fennáll. Innentől kezdve nem lehet a prevenció elsődleges célja az információátadás.

A hosszabb távra kidolgozott prevenciós stratégiának arra is figyelnie kell, hogy a technika és a fogyasztási szokások változása időnként tálcán kínálja a váratlan megoldásokat. Bizonyára minden olvasó emlékszik arra, hogy az 1970-es évtizedtől kezdve általános volt az aggodalom, hogy az iskolás gyermekek túlságosan sok időt töltenek a televízió képernyője előtt - naponta akár 3-4 órát is. Később már nem a tv-t, hanem a számítógépes játékokat tekintették hasonló veszélyforrásnak a pedagógusok. A fö aggodalom az volt, hogy mindez rontja a gyermekek kommunikációs készségeit, befelé fordulásra szoktat, fokozza az agresszivitást, emiatt van az elhízás stb. Mára viszont mindezek a tevékenységek visszaszorultak - de nem azért, mert az iskola lebeszélő programjai eredményesek

6 Óriási irodalom igazolja, hogy ezek a „jobb” családba született gyermekek felnőtt korukban azután saját gyermekeikre is átörökítik vagyonukat, társadalmi előnyeiket és privilégiumaikat (Mihályi-Szelényi 2016).

7 Lásd erről W. Mischel rövid videointerjúját itt: https:/www.youtube.com/watch?v=XcmrCLL7Rtw [Letöltve: 2019. nov. 27.]

8 Elkeserítő példa erre Semsey (2018) terjedelmes és bőséges irodalmi hivatkozással ellátott tanulmánya, amely a "Szexuális nevelés az iskolában” címmel jelent meg a közelmúltban, ám egyetlen szóval sem említi az internetet vagy a Google kereső programot. 
voltak. A technika - tegyük hozzá: az importált technika - a közösségi média használata felé tolta el a fiatalokat, s ez éppenséggel nagyon is fejleszti a gyermekek kommunikációs skilljeit.

Nagy dilemmája a káros szenvedélyek ellen küzdő közpolitikának, hogy miként befolyásolja a közvetlenül érintett termékek árait és a hozzáférés lehetőségeit. Az elmúlt évtized során, két területen is melléfogott a népegészségügyi kormányzat. A 2. Orbánkormány egyik legelső parlamenti döntésével minden felnőtt magyar állampolgár számára lehetővé tette az otthoni pálinkafözést - akkor is, ha boltban vásárolta a gyümölcsöt -, és egyúttal adómentessé is tette a tevékenységet. Népegészségügyi szempontból azonban nagyon káros volt a pálinkafózés liberalizációja, mivel az otthoni, kisipari lepároló berendezések használatával nyert desztillált alkohol sokkal több mérgező fémszennyeződést tartalmaz, mint a nagyipari berendezések által gyártott párlat. Erről a közvélemény általában, a fiatalok pedig különösen ritkán hallanak. Még jó pár évig az iskola feladata marad ezt megtanítani.

A másik elhibázott döntés a dohány-kiskereskedelem monopolpiaccá alakítása volt. Az elképzelés az volt, és ez 2013. július 1-től meg is valósult, hogy az értékesítő helyek száma 42 ezerről 7 ezerre fog csökkenni, és egyúttal megemelkednek a cigarettaárak is. Mint az várható is volt (Mihályi 2012), a kis- és nagykereskedelmet egyaránt érintő korlátozások nyomán nőtt a feketekereskedelem. Ennél is fontosabb és váratlan fejlemény volt, hogy a cigarettaforgalom visszaesésével párhuzamosan sokszorosára nőtt a vágott dohány eladása. Ez részint az alacsonyabb adókulcs miatt történt így, részint amiatt, hogy a korábbi 1000 dohánybolt helyett ötször annyi dohánybolt kínált vágott dohányt nagy kiszerelésben és nagy választékban - vagyis bővültek a hozzáférés lehetőségei. A rendszeres dohányzók aránya nem csökkent, ami egyben annyit is jelent, hogy a vágott dohány növekvő aránya miatt a tényleges nikotinfogyasztás valójában még nőtt is! $\mathrm{Az}$ egyik legismertebb hazai dohányzás-problémákra specializálódott népegészségügyi szakember, Bodrogi József az Eurobarométer adataira hivatkozva 2019 elején megerősítette, hogy míg 2014-ben a 14 és 25 éveseknek a 25 százaléka cigarettázott, addig 2018 végére ez az arány már 39 százalék volt. ${ }^{9}$

A fenti két példa a kormányzat hibás politikáját illusztrálja, de történt ennél súlyosabb dolog is, ám ebben nem érhető tetten a kormányzat felelőssége. A világ drogpiacait egyre inkább a szintetikus (vagy más néven: dizájner) drogok uralják. Ezek erősebb hatást fejtenek ki, mint a marihuána, és ami a legfontosabb, a fekete piaci áruk is csak töredéke az 5-10 évvel ezelőtt kapható drogokénak. Ráadásul az egyik népszerü drog, a herbál legálisan elérhető szintetikus anyagokból „készül”, s emiatt nem minősül kábítószernek. A Bűnügyi Szakértői és Kutatóintézet adatai szerint az új szerek 2009 környékén kezdek elterjedni Magyarországon: míg 2009-2010 között a marihuána tette ki a rendőrség által lefoglalt drogok túlnyomó részét, addig 2014-ben az új anyagok a lefoglalt szerek 60 százalékát tették ki, a herbál pedig kétszeresen is megelőzte a marihuánát. A herbál népszerüsége olcsóságából is adódik: 2015-ben egy gramm 600-700 forintért már megvásárolható volt. Ez különösen a szegregátumokban élő roma gyermekek számára vonzó. ${ }^{10}$

9 Danó 2019.

10 Rádi (2019) terjedelmes tanulmánya megyei szintre lebontva mutatja be az országos helyzetet. 
A cigarettaként elszívható herbált a dílerek és a fogyasztók sokszor „biofünek” is nevezik, pedig valójában semmi bio nincs benne: az anyagot szintetikusan állítják elő, amit aztán növényi törmelékekhez kevernek. ${ }^{11} \mathrm{~A}$ herbál az iskola szempontjából is rosszabb, mint a marihuána, mert a függőség időben erősebb kényszert teremt. Magyarán, a gyerekek - az általános iskola felső tagozatos diákjai is (!) - „rákényszerülnek” arra, hogy az iskolában, a szünetekben is szívjanak. Az iskolák kezében jelenleg egyetlen fegyver van: a kábítószer-fogyasztáson ért diákokat kicsapják a tanintézetből.

\section{A bajok gyökerét nem lehet orvosolni}

$\mathrm{A} z$ iskolai prevencióval, a gyermekek közötti egyenlötlenségekkel foglalkozó elméleti szakemberek és a terepen dolgozó kollégák egyaránt tudják, és nagyon sokszor elmondják, hogy a problémák mélyen húzódó gyökerei a szegénységgel, a szegregációval és a többségi társadalom (a középosztály) elöítéletességével vannak szoros kapcsolatban. Nyilvánvaló, hogy az lenne a hatásos gyógymód minden e cikkben megemlített területen, ha meg lehetne szüntetni a társadalmi egyenlőtlenségeket. Meggyőződésem szerint azonban az iskolai prevenciós stratégiát ezzel éppen ellentétes logikával célszerü végiggondolni, és azután részleteiben is kidolgozni. Abból kell kiindulni, hogy a társadalmi egyenlőtlenségek Magyarországon a belátható jövőben - mondjuk négy-öt évtized során - számos ok miatt fenn fognak maradni, sőt inkább nőni fognak, mint csökkenni. Hely hiányában csak egyetlen összefüggést említek. Gondoljunk csak arra, hogy az elmúlt 8-10 évben mennyire felgyorsult a külföldi munkavállalás. Ez azt jelenti, hogy pár év múlva a magyar középosztályi családok többségének lesz valamiféle „nyugati” bázisa, ahonnan jövedelmet fog húzni, viselkedésmintákat fog örökölni. Ez is egy ok arra, hogy a közösségi forrásokból finanszírozott hazai iskolai prevenció a legszegényebb, legelesettebb családok gyermekeinek a szükségleteiből induljon ki.

\section{IRODALOM}

Balázs P., Rákóczi I., Grenczer A. \& Foley K. (2012) Várandósok egészségi állapota Magyarországon, roma és nem roma populációban végzett epidemiológiai kutatás alapján. Népegészségügy, Vol. 90. No. 4. pp. 253-263.

Danó Anna (2019) Szakaszgyőzelmet aratott a dohánylobbi. Népszava, febr. 15. https:// nepszava.hu/3025532_szakaszgyozelmet-aratott-a-dohanylobbi [Letöltve: 2019. nov. 27.]

EMMI (2018) EMMI módszertani levele a 2018. évi védőoltásokról. https://www.antsz.hu/ data/cms84807/EMMI_VML2018_kozlony.pdf

MinÁlyi Péter (2012) A dohánykereskedelem korlátozása árt az egészségnek. Népszabadság, jan. 7.

Mihályi Péter \& Szelényi Iván (...) Az egyenlőtlenségek valódi természetéről. Mozgó Világ, Vol. 42. No. 11. pp. 3-12.

OGYI (2009) Országos Gyermekegészségügyi Intézet (2009): Nemzeti Gyermek-és Ifjúságbiztonsági Akcióterv 0-24 évesek véletlen baleseteinek megelözési programja 2010-2019. Bp. https://www.childsafetyeurope.org/europe/info/hungary/hungary-planning-documenthu.pdf [Letöltve: 2019. 08. 21.]

11 Népszava, 2015. jún. 26. 
Rádi Antónia (2019, ed.) Pár nap kristályozás meg egy kis biofü és kész az alföldi Walking Dead - droghasználati szokások a magyar vidéken. https://atlatszo.hu/2019/01/08/parnap-kristalyozas-meg-egy-kis-biofu-es-kesz-az-alfoldi-walking-dead-droghasznalatiszokasok-a-magyar-videken/ [Letöltve: 2019. nov. 27.]

Semsey Gábor (2018) Szexuális nevelés az iskolában. Iskolakultúra, Vol. 28. No. 12. pp. 17-34. DOI: 10.17543/ISKKULT.2018,12.17.

A cikk a Creative Commons Attribution 4.0 International License (https://creativecommons.org/licenses/ by/4.0/) feltételei szerint publikált Open Access közlemény, melynek szellemében a cikk bármilyen médiumban szabadon felhasználható, megosztható és újraközölhető, feltéve, hogy az eredeti szerző és a közlés helye, illetve a CC License linkje és az esetlegesen végrehajtott módosítások feltüntetésre kerülnek. (SID_1) 